\title{
Identifikasi Awal Bakteri pada Juwana Trochus niloticus Linn. dan Tridacna squamosa Linn. Asal Hatchery Pulau Barrang Lompo Makassar
}

\section{Early Identification of Bacteria of Juveniles Trochus niloticus Linn. and Tridacna squamosa Linn. from Hatchery Barrang Lompo Island Makassar}

\author{
Magdalena Litaay ${ }^{1,2 *}$, Risco B. Gobel ${ }^{1}$, As'adi Abdullah¹, Subair ${ }^{1}$ \\ ${ }^{1}$ Jurusan Biologi FMIPA Universitas Hasanuddin, Makassar \\ E-mail: magdalenalitaay@yahoo.com *Penulis untuk korespondensi \\ ${ }^{2}$ Pusat Penelitian Terumbu Karang Universitas Hasanuddin, Makassar
}

\begin{abstract}
The research on early identification of bacterial from juveniles top shell (Trochus niloticus L.) and giant clam (Tridacna squamosa Linn.) was conducted at Unhas's hatchery at Barrang Lompo island during August-October 2006. Bacteriology test was done at Microbiology Laboratory of Biology Department, Math and Science Faculty, Hasanuddin University, Makassar. The quantitative test was done using Most Probable Number (MPN) and Standard Plate Count (SPC) methods. While the qualitative test included bacteria colony observation, macroscopic, microscopic, and biochemical test. Macroscopic observation was done by assessing the form, elevation, color, ridge, and inner structure of bacterial colony. Microscopic observation was conducted by using Gram and spora stain. The result of MPN method shows the average total bacteria for juveniles top shell is $17.5 \times 10^{2} \mathrm{cell} / \mathrm{ml}$ and for giant clam is $6.65 \times 10^{2} \mathrm{cell} / \mathrm{ml}$, while SPC results indicate the average total bacteria for juveniles top shell is $4.8 \times 10^{5} \mathrm{cell} / \mathrm{ml}$ and for giant clam is $3.0 \times 10^{5} \mathrm{cell} / \mathrm{ml}$, respectively. The result of biochemical test identifies 5 genera of bacteria such as Micrococcus, Bacillus, Streptomyces, Escherichia and Enterobacter.
\end{abstract}

Key words: bacteria, isolation and identification, top shell, giant clam

Diterima: 24 Maret 2007, disetujui: 24 Agustus 2007

\section{Pendahuluan}

Kima sisik (Tridacna squamosa Linn.) dan Lola (Trochus niloticus L.) telah diketahui merupakan biota laut yang bernilai ekonomis, keduanya memiliki cangkang yang dapat dimanfaatkan sebagai bahan perhiasan, bahan baku industri, dan dagingnya dapat dikonsumsi. Besarnya permintaan dari dalam dan luar negeri menyebabkan terjadinya penangkapan yang intensif dan tingginya tingkat eksploitasi, sehingga keduanya semakin langka dan termasuk biota yang dilindungi oleh pemerintah sesuai peraturan pemerintah No. 7 Tahun 1999 (Marwoto, 2001; Nontji, 2002).
Usaha untuk melestarikan kedua biota laut tersebut dapat dilakukan dengan upaya budidaya. Pada pembudidayaan kekerangan beberapa aspek yang menjadi penentu keberhasilan kegiatan tersebut diantaranya lokasi, induk dan benih, teknik budidaya, penanggulangan penyakit, pasca panen, dan pemasaran (Anonim, 2005). Budidaya lola dan kima telah dilakukan di beberapa tempat di Indonesia. Di hatchery Universitas Hasanuddin pulau Barrang Lompo budidaya lola dan kima lebih diperuntukan untuk tujuan penelitian, aspek-aspek yang telah dikaji didominasi oleh aspek biologi, kimia maupun fisika (Suaib, 1995; Marwan, 1996; Armand, 1999; Niartiningsih, 2000, 2001; Niartiningsih et al., 2004a,b; Litaay et al., 2006a,b; Yusuf et al., 
2006), namun penelitian khusus tentang aspek bakteriologis hewan budidaya masih minim. Padahal aspek ini salah satu unsur penting dalam budidaya perikanan, terutama bila produk budidaya diperuntukkan untuk tujuan konsumsi (Ekawati \& Mursyanti, 2006).

Sumber air yang digunakan dalam usaha marikultur yang berasal dari laut yang letaknya dekat dengan pemukiman penduduk dapat tercemar oleh buangan limbah dari rumah tangga atau lainnya. Di sisi lain, pada lingkungan hatchery akuatik dapat ditemukan komunitas mikroba yang bervariasi dari bakteri yang menguntungkan hingga merugikan atau patogenik (Schulze et al., 2006). Penelitian ini bertujuan untuk mengetahui bakteri yang terdapat pada sampel juwana lola dan kima sisik asal hatchery setempat.

\section{Metode Penelitian}

\section{Bahan}

Pelaksanaan penelitian berlangsung pada bulan Agustus - Oktober 2006. Sampel juwana lola dan kima sisik berasal dari hatchery pulau Barrang Lompo dan analisis bakterilogis dikerjakan di Laboratorium Mikrobiologi, Jurusan Biologi, FMIPA Universitas Hasanuddin, Makassar. Sampel juwana lola yang berumur 5 bulan dan kima sisik berumur 3 bulan hasil pemijahan hatchery setempat. Pengambilan sampel bakteri pada bagian cangkang menggunakan metoda swab steril yang terlebih dahulu telah direndam dalam larutan buffer fosfat $/ \mathrm{NaCl} 0,85 \%$, sedangkan bagian visceral dihaluskan menggunakan blender. Hasil yang disajikan merupakan hasil analisis gabungan antara kedua bagian tubuh hewan uji yang digunakan.

\section{Lokasi}

Uji coba pemijahan kima di hatchery Universitas Hasanuddin P. Barrang Lompo telah dimulai tahun 1994, yang selanjutnya diikuti oleh lola dan beberapa komoditi lain. Air laut yang digunakan di hatchery pulau Barrang Lompo sebagai medium budidaya berasal dari perairan sekitar, dialirkan ke hatchery melalui filtrasi bertingkat. Air yang digunakan untuk media pemeliharaan hewan budidaya telah melalui penyaringan bertingkat mulai dari ijuk kemudian saringan filter bag 5 dan 1 mikron untuk larva. Sedangkan untuk pemeliharaan juwana menggunakan saringan 10-25 mikron. Prosedur sanitasi dan penggantian air di hatchery mengikuti petunjuk operasional setempat.

\section{Cara Kerja}

Pemeriksaan bakteriologis secara kuantitatif dan kualitatif mengikuti prosedur yang digunakan di Laboratorium Mikrobiologi FMIPA Universitas Hasanuddin. Semua medium yang digunakan disterilkan dengan menggunakan autoklaf pada suhu $121^{\circ} \mathrm{C}$, tekanan 2 atm selama 15 menit. Medium yang digunakan antara lain Hadioetomo, 1990; Bergey et al., 1994; Ekawati \& Mursyanti, 2006): Nutrient Agar (NA), Sulfida Indol Motility Agar (SIM), Lactosa Broth (LB), Triple Sugar Iron Agar (TSIA), Simmon Citrat Agar (SCA), Eosin Methylene Blue Agar (EMBA), Methyl Red Voger Proskauer (MRPV), Salmonella Shigella Agar (SSA).

Uji kuantitatif meliputi penghitungan jumlah total bakteri dengan metode Standar Plate Count (SPC), total bakteri dihitung menggunakan rumus: F1 Jumlah koloni/ml sampel = Jumlah koloni dalam cawan $\mathrm{x}$ 1/Faktor pengenceran. Cawan yang dipakai dan dihitung adalah yang mengandung jumlah koloni 30 - 300. Jumlah bakteri coliform dihitung menggunakan metode Most Probable Number $(M P N), M P N$ count $=$ Nilai $M P N \times$ $1 /$ pengenceran tabung tengah. Nilai $M P N$ dari tabel MPN 3 seri.

Uji kualitatif meliputi pengamatan makroskopis bakteri (morfologi: bentuk, permukaan, tepi, elevasi, struktur dalam dan warna koloni) dan mikroskopis sesuai standar karakteristik bakteri. Identifikasi bakteri menggunakan beberapa uji seperti: Katalase; Hidrogen Sulfida $\left(\mathrm{H}_{2} \mathrm{~S}\right)$; Indol dan Motilitas; Sitrat; Methyl Red dan uji Voges Proskaeur.

\section{Hasil dan Pembahasan}

\section{Total bakteri - metode $S P C$}

Hasil perhitungan jumlah total bakteri menggunakan metode SPC menunjukkan rata- 
rata total bakteri pada lola sebesar $4,8 \times 10^{5}$ $\mathrm{sel} / \mathrm{ml}$ dan kima $3,0 \times 10^{5} \mathrm{sel} / \mathrm{ml}$. Hasil penelitian Lejab (2006) tentang uji kualitas air pada hatchery di pulau Barrang Lompo menunjukkan bahwa sistem penyaringan/filter (max $1 \mu$ ) yang digunakan mampu mengurangi jumlah bakteri yang masuk ke bak pemeliharaan larva dari 5,0 $\times 10^{7}$ berkurang hingga $8,6 \times 10^{6} \mathrm{sel} / \mathrm{ml}$. Total bakteri pada juwana hewan uji lebih tinggi dibanding hasil Lejab (2006) walaupun air yang digunakan pada medium hidup juwana disaring dengan saringan $10 \mu$. Hal ini menunjukkan bahwa hewan uji mempunyai mekanisme tersendiri dalam memfilter benda asing yang masuk ke tubuh.

\section{Total bakteri coliform - metode $M P N$}

Hasil perhitungan jumlah total bakteri menggunakan metode MPN menunjukkan hasil bahwa rata-rata total bakteri coliform pada sampel lola sebesar $17,5 \times 10^{2} \mathrm{sel} / \mathrm{ml}$ dan pada kima $6,65 \times 10^{2} \mathrm{sel} / \mathrm{ml}$. Tingginya jumlah total bakteri coliform pada kedua organisme tersebut dimungkinkan karena saringan yang digunakan dapat meloloskan bakteri ke dalam medium air. Bakteri laut yang bersama dengan alga uniselular diatom membentuk biofilm pada permukaan substrat dasar beton bak pemeliharaan merupakan makanan bagi lola. Standar Dirjen POM No: 03726/B/SK/VII/89 untuk tujuan konsumsi, menunjukkan nilai MPN yang diperoleh untuk kedua organisme tersebut berada di atas standar kualitas normal / baku yakni $4 \times 10^{2} \mathrm{sel} / \mathrm{ml}$. Namun peruntukan produksi juwana melalui hatchery ini untuk tujuan penebaran kembali di alam, sehingga jumlah tersebut masih dapat diterima.

\section{Pengamatan morfologi koloni isolat bakteri pada medium nutrient agar (NA)}

Hasil pengamatan morfologi bakteri dapat dilihat pada Tabel 1, 11 isolat diisolasi dari sampel lola (5 isolat: L1, L2, L3, L4 dan L5) dan kima 6 isolat $(\mathrm{K} 1, \mathrm{~K} 2, \mathrm{~K} 3, \mathrm{~K} 4, \mathrm{~K} 5$ dan K6).

Tabel 1. Karakteristik koloni isolat bakteri pada medium NA

\begin{tabular}{|c|c|c|c|c|c|c|c|}
\hline \multirow{2}{*}{ Sampel } & \multirow{2}{*}{ Isolat } & \multicolumn{6}{|c|}{ Ciri Pertumbuhan Koloni } \\
\hline & & Bentuk & Tepi & Elevasi & Warna & Permukaan & Struktur Dalam \\
\hline \multirow{5}{*}{ Lola } & 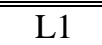 & Circulair & Entire & Law Convex & Kuning & Licin & Opaque \\
\hline & L2 & Irreguler & Undulate & Umbonate & Krem & Licin & Coarsly granular \\
\hline & L3 & Circulair & Entire & Convex & Orange & Licin & Opaque \\
\hline & L4 & Irreguler & Undulate & Umbonate & Krem & Licin & Coarsly granular \\
\hline & L5 & Circulair & Entire & Effuse & Kuning muda & Kering & Opaque \\
\hline \multirow{6}{*}{ Kima } & K1 & Circulair & Undulate & Law Convex & Kuning & Licin & Transclucent \\
\hline & $\mathrm{K} 2$ & Circulair & Entire & Convex & Kuning & Licin & Opaque \\
\hline & K3 & Irreguler & Undulate & Umbonate & Krem & Licin & Coarsly granular \\
\hline & $\mathrm{K} 4$ & Toruloid & Lobate & Effuse & Krem & Licin & Transclucent \\
\hline & K5 & Circulair & Undulate & Raised with concave & Krem & Kering & Opaque \\
\hline & K6 & Circulair & Entire & Effuse & Krem & Kering & Opaque \\
\hline & : bulat & & & & \\
\hline \multicolumn{3}{|c|}{$\begin{array}{r}\text { Keterangan: Circulair } \\
\text { Irregular }\end{array}$} & : tidak $\mathrm{b}$ & beraturan & & & \\
\hline \multicolumn{3}{|c|}{ Lobate } & : terdap & at bentuk-bentuk sep & erti telinga & & \\
\hline \multicolumn{3}{|c|}{ Undulate } & : terdap & at bentuk-bentuk sep & erti gerigi & & \\
\hline \multicolumn{3}{|c|}{ Entire } & : rata & & & & \\
\hline \multicolumn{3}{|c|}{ Convex } & : cembu & & & & \\
\hline \multicolumn{3}{|c|}{ Opaque } & : tidak $\mathrm{t}$ & tembus cahaya & & & \\
\hline & \multicolumn{2}{|c|}{ Transparan } & : dapat & tembus cahaya & & & \\
\hline & \multicolumn{2}{|c|}{ Coarsly greanular } & : Butira & in-butiran halus & & & \\
\hline & \multicolumn{2}{|c|}{ Law convex } & : Agak & cembung & & & \\
\hline & \multicolumn{2}{|c|}{ Raised with concave } & : Bergel & lombang dengan bag & an tengah berb & ntuk kawah & \\
\hline
\end{tabular}




\section{Pengamatan secara mikroskopik}

Hasil pengecatan Gram menunjukkan bahwa bakteri yang terdapat pada sampel kerang lola dan kima umumnya Gram positif kecuali isolat L5, K4, dan K6 (Tabel 2). Semua isolat yang diidentifikasi merupakan bakteri yang berbentuk batang (bacil). Pengecatan Gram merupakan salah satu teknik pewarnaan differensial yang penting dan paling umum digunakan untuk mengelompokkan bakteri menjadi kelompok yaitu bakteri gram positif dan negatif (Volk \& Wheeler, 1993).

Hasil pengamatan menunjukkan bahwa secara umum isolat mampu menghasilkan spora kecuali isolat L5, K4, dan K6. Spesiesspesies tertentu merupakan bakteri yang menghasilkan spora baik itu di dalam sel vegetatif (endospora) ataupun di luar sel (eksospora). Spora merupakan bagian tubuh yang secara metabolik berperan dalam masa dorman, yang dihasilkan pada fase lanjut dari pertumbuhan sel, dan pada kondisi-kondisi yang tidak sesuai. Spora bersifat tahan terhadap gangguan fisik misalnya panas dan juga gangguan kimiawi misalnya desinfektan.

\section{Pengamatan uji fisiologis dan biokimia}

\section{Uji TSIA}

Sebelas isolat pada uji TSIA memperlihatkan adanya perubahan warna medium dari merah menjadi kuning, yang menunjukkan terjadinya perubahan $\mathrm{pH}$ pada medium dari netral menjadi asam. Hal ini berarti bahwa laktosa atau sukrosa atau keduanya difermentasikan oleh isolat tersebut. Menurut Lay (1994), uji TSIA digunakan terutama untuk mengidentifikasi bakteri gramnegatif. Sedangkan bila tidak terjadi perubahan warna pada medium berarti medium bersifat basa karena isolat bakteri tersebut tidak memfermentasikan ketiga macam gula. Hanya isolat L5 dan K6 menghasilkan gas sedang isolat lainnya tidak (Tabel 3).

Terbentuknya gas diindikasikan dengan terangkatnya medium dan diikuti oleh adanya retakan pada dasar medium. Selanjutnya pembentukan $\mathrm{H}_{2} \mathrm{~S}$ tidak terlihat dari keseluruhan isolat kecuali isolat K5. Ini membuktikan bahwa hampir semua isolat hasilnya negatif saat diuji karena tidak mampu menguraikan asam amino yang mengandung sulfur. Pembentukan $\mathrm{H}_{2} \mathrm{~S}$ oleh mikroorganisme menunjukkan adanya penguraian asam amino yang mengandung sulfur. Penguraian asam amino tersebut dapat terjadi karena kemampuan mikroorganisme menghasilkan desulfurase (Lay, 1994). $\mathrm{Fe}^{3+}$ yang terdapat dalam medium biakan bereaksi dengan $\mathrm{H}_{2} \mathrm{~S}$ dan menghasilkan senyawa $\mathrm{FeS}$ yang berwarna hitam dan tidak larut dalam air. Lebih lanjut menurut Cappucino and Sherman (1992) bahwa medium TSIA juga mengandung substrat untuk produksi gas dan $\mathrm{H}_{2} \mathrm{~S}$. Senyawa $\mathrm{FeSO}_{4}$ digunakan untuk mendeteksi adanya gas $\mathrm{H}_{2} \mathrm{~S}$ yang tidak berwarna sebagai hasil metabolisme sel.

Tabel 2. Karakteristik isolat bakteri secara mikroskopik

\begin{tabular}{cccc}
\hline \hline \multirow{2}{*}{ Isolat Bakteri } & \multirow{2}{*}{ Bentuk Sel } & \multicolumn{2}{c}{ Pewarnaan } \\
\cline { 3 - 4 } & Batang & Gram & Spora \\
\hline \hline L1 & Batang & Positif & Ada \\
L3 & Positif & Ada \\
L4 & Batang & Positif & Ada \\
L5 & Batang & Positif & Ada \\
K1 & Batang & Negatif & Tidak ada \\
K2 & Batang & Positif & Ada \\
K3 & Batang & Positif & Ada \\
K4 & Batang & Positif & Ada \\
K5 & Batang & Negatif & Tidak Ada \\
K6 & Batang & positif & Ada \\
\hline \hline
\end{tabular}




\section{Uji sitrat}

Hasil uji sitrat menunjukkan 11 isolat bersifat negatif dan 2 isolat positif (isolat $\mathrm{K} 4$ dan K5). Hasil positif yang diperlihatkan 11 isolat tersebut menunjukkan bahwa isolat bakteri yang terdapat pada kerang lola dan kima mampu menggunakan sitrat sebagai sumber karbon.

\section{Uji indol}

Secara umum isolat memperlihatkan reaksi negatif pada uji indol ditandai tidak adanya perubahan warna medium pada permukaan setelah ditetesi reagen (Tabel 3). Hal ini menunjukkan bahwa semua isolat tidak menggunakan triptofan kecuali isolat L5 dan K6 yang hasilnya positif setelah medium ditetesi reagen menunjukkan adanya pembentukan cincin warna merah pada permukaan medium. Hal ini dimungkinkan karena kemampuan bakteri tersebut menggunakan triptofan sebagai sumber karbon.

Pengujian isolat bakteri pada uji indol dimana isolat tersebut ditumbuhkan pada medium SIM yang kaya akan asam amino triptofan. Menurut Lay (1994), asam amino triptofan merupakan asam amino (AA) yang lazim terdapat pada protein, akibat hidrolisasi protein, AA ini dengan mudah digunakan oleh mikroorganisme. Pembentukan indol dari triptofan oleh mikroorganisme dapat diketahui dengan penambahan reagen Kovac's yang mengandung para-dimetil-aminobenzaldehida. Reagen bereaksi dengan indol dan menghasilkan senyawa yang tidak larut dalam air dan warna medium menjadi merah pada bagian permukaan. Kemampuan dalam menghidrolisis triptofan menjadi indol tidak dapat dilakukan oleh semua bakteri oleh karenanya dapat dijadikan ciri fisiologi (Pelczar \& Chan, 1986).

\section{Uji Methyl Red}

Pada hasil uji MR, lima isolat memperlihatkan hasil negatif, ditandai oleh medium tetap berwarna kuning setelah ditetesi dengan reagen, pertanda ke-5 isolat tersebut medium pertumbuhannya memiliki $\mathrm{pH}$ di atas 6,2. Sedangkan isolat L2, L4, K3, K5, L5, dan K6 tetap berwarna merah, indikasi mikroorganisme tersebut mampu memfermentasi 2,3 butanadiol.

Pengujian MR bertujuan untuk menentukan adanya fermentasi asam campuran. Bakteri memfermentasikan glukosa dan menghasilkan berbagai produk yang bersifat asam sehingga akan menurunkan $\mathrm{pH}$ medium pertumbuhan menjadi 5,0 atau lebih rendah. Penambahan MR dapat menunjukkan adanya perubahan $\mathrm{pH}$ menjadi asam. Bila terjadi fermentasi asam campuran medium biakan yang telah ditambahkan MR akan tetap berwarna merah.

Tabel 3. Hasil pengamatan uji biokimia isolat bakteri sampel lola dan kima

\begin{tabular}{|c|c|c|c|c|c|c|c|c|c|c|c|}
\hline \multirow{3}{*}{ Isolat } & \multicolumn{10}{|c|}{ Uji Fisiologi } & \multirow{3}{*}{ Genera Bakteri } \\
\hline & \multicolumn{4}{|c|}{ TSIA } & \multirow{2}{*}{ Ind } & \multirow{2}{*}{ MR } & \multirow{2}{*}{ VP } & \multirow{2}{*}{ Sit } & \multirow{2}{*}{ Kat } & \multirow{2}{*}{ Mot } & \\
\hline & Asam & Basa & Gas & $\mathrm{H}_{2} \mathrm{~S}$ & & & & & & & \\
\hline L1 & + & - & - & - & - & - & - & - & + & - & Micrococcus \\
\hline L2 & + & - & - & - & - & + & - & - & + & + & Bacillus \\
\hline L3 & + & - & - & - & - & - & - & - & + & - & Micrococcus \\
\hline L4 & + & - & - & - & - & + & - & - & + & + & Bacillus \\
\hline L5 & + & - & + & - & + & + & - & - & + & + & Escherichia \\
\hline K1 & + & - & - & - & - & - & - & - & + & - & Micrococcus \\
\hline K2 & + & - & - & - & - & - & - & - & + & - & Micrococcus \\
\hline K3 & + & - & - & - & - & + & - & - & + & + & Bacillus \\
\hline K4 & + & - & - & - & - & - & + & + & + & + & Enterobacter \\
\hline K5 & + & - & - & + & - & + & - & + & - & + & Streptomyces \\
\hline K6 & + & - & + & - & + & + & - & - & + & + & Escherichia \\
\hline
\end{tabular}

Keterangan: Asm: asam, Kat: Katalase, MR: Methyl Red, VP: Voges Proskaeur, Ind: Indol, Sit: sitrat, Urea: hidrolisis urea, $\mathrm{H}_{2} \mathrm{~S}$ : Hidrogen Sulfita , TSIA: Triple Sugar Iron Agar, mot: motil. + = Hasil uji positif, - = Hasil uji negatif 


\section{Uji Voges Proskauer}

Hasil uji VP memperlihatkan hasil positif untuk semua isolat kecuali isolat K4. Menurut Lay (1994) bila bakteri memfermentasikan karbohidrat menjadi 2,3 butanadiol sebagai produk utama, akan terjadi penumpukan bahan tersebut dalam medium pertumbuhan. Hasil positif ditandai dengan perubahan warna medium menjadi merah muda, ini menunjukkan kemampuan isolat bakteri dapat memfermentasi 2,3 butanadiol, sedangkan hasil yang negatif ditandai dengan tidak terjadi perubahan warna medium. Dari hasil uji ini, secara umum semua bakteri pelarut fosfat mampu menghasilkan 2,3 butanadiol.

\section{Uji katalase}

Uji katalase memperlihatkan 11 isolat bakteri yang mampu menghasilkan enzim katalase, kecuali isolat K5. Hal ini ditandai dengan terbentuknya gelembung udara pada objek glass setelah ditetesi dengan pereaksi $\mathrm{H}_{2} \mathrm{O}_{2} 3 \%$. Menurut Lay (1994) katalase adalah enzim yang mengandung $\mathrm{Fe}$ yang mengkatalisis reaksi hidrogen peroksida $\left(\mathrm{H}_{2} \mathrm{O}_{2}\right)$ menjadi air dan oksigen. Selanjutnya, Hadioetomo (1990) menambahkan, umumnya bakteri aerob dan anaerob fakultatif akan menghasilkan hidrogen peroksida yang bersifat racun terhadap sistem enzimnya sendiri. Namun, mikroorganisme tersebut dapat hidup dengan adanya senyawa tersebut karena dihasilkannya enzim yang dapat mengubah hidrogen peroksida menjadi air dan oksigen.

\section{Uji motilitas}

Pada hasil uji motilitas, umumnya isolat memperlihatkan pertumbuhan menyebar yang menandakan adanya sifat motil dari isolat, kecuali isolat L1, L3, K1, dan $\mathrm{K} 2$ yang bersifat non-motil.

Berdasarkan hasil pengamatan morfologi koloni, morfologi sel dan uji fisiologis (uji TSIA, uji motilitas, indol, sitrat, pembentukkan $\mathrm{H}_{2} \mathrm{~S}$ dan gas), isolat $\mathrm{L} 2$, L4, dan $\mathrm{K} 3$ memiliki karakter yang sama dengan bakteri dari Bacillus. Menurut Bergey et al., (1994) dan Mac Fadden (1991) Bacillus termasuk bakteri Gram positif, berspora, katalase positif, MR positif atau negatif, VP positif atau negatif, dan bersifat motil atau nonmotil serta menunjukkan hasil yang negatif terhadap indol. Bacillus, dominan pada sampel hewan uji dimungkinkan karena golongan bakteri ini membentuk endospora memiliki toleransi yang tinggi terhadap lingkungan.

Isolat L1, L3, K1, dan $\mathrm{K} 2$ memiliki karakter yang sama terhadap kelompok bakteri dari genus Micrococcus. Menurut Cappucino dan Sherman (1992), genus Micrococcus termasuk bakteri Gram positif, berspora, katalase positif, MR dan VP negatif, dan bersifat motil atau nonmotil serta menunjukkan hasil yang negatif terhadap indol.

Isolat K4 memiliki karakter yang sama terhadap bakteri genus Enterobacter, diperkuat dengan hasil uji VP, sitrat, katalase dan motilitas negatif sedangkan untuk gas, $\mathrm{H}_{2} \mathrm{~S}$, indol dan MR menunjukkan hasil positif.

Isolat K5 memiliki karakter yang sama terhadap kelompok bakteri dari genus Streptomyces yakni ditandai adanya pembentukan gas, dan pada uji indol, VP dan katalase menunjukkan hasil negatif sedangkan untuk $\mathrm{H}_{2} \mathrm{~S}$, MR, sitrat dan motil menujukkan hasil yang positif. Selanjutnya, isolat L5 dan K6 (Tabel 2) memiliki kesamaan ciri dengan bakteri kelompok Escherichia, termasuk bakteri gram negatif, nonspora, membentuk gas, indol MR, katalase dan motilitas menunjukkan hasil negatif sedangkan untuk uji $\mathrm{H}_{2} \mathrm{~S}$ dan sitrat menujukkan hasil positif (Bergey et al., 1994).

Pertumbuhan dan penyebaran bakteri dipengaruhi oleh faktor suhu dan salinitas air. Bakteri laut dapat hidup pada kisaran suhu dan salinitas yang luas. Menurut Volk dan Wheeler (1993) bahwa bakteri laut dapat tumbuh pada kisaran $20-40^{\circ} \mathrm{C}$. Suhu air yang tercatat di hatchery $28^{\circ} \mathrm{C}-30^{\circ} \mathrm{C}$ dan salinitas $31 \%-35 \%$. Selain itu $\mathrm{pH}$ juga dapat mempengaruhi aktifitas biologi di air, rata-rata $\mathrm{pH}$ air pada hatchery adalah 8,02. Menurut Rheinheimer (1992) pertumbuhan optimal yang baik untuk bakteri laut adalah pada $\mathrm{pH}$ antara 6,5 - 8,5. Faktor lain yang juga merupakan elemen yang penting dalam pengendalian kualitas air adalah oksigen. Nilai oksigen terlarut (DO) pada medium air hatchery berkisar antara 5-6 ppm, cukup ideal untuk pertumbuhan bakteri.

Bakteri dan mikroorganisme lain dapat ditemukan hidup di berbagai habitat di 
lingkungan laut. Diversitas taksonomi bervariasi, aktif dan ditemukan hidup pada laut yang dalam sampai daerah dangkal estuari (Austin, 1988; Rheinheimer, 1992). Penelitian sebelumnya menyebutkan bahwa plankton bakteri didominasi bakteri Gram negatif (Gontang et al., 2007). Selain itu, peneliti ini juga menemukan variasi cukup tinggi pada bakteri gram positif yang disolasi dari sedimen laut yang berasal dari daerah intertidal sampai kedalaman $500 \mathrm{~m}$, dengan $65,6 \%$ dari bakteri yang teridentifikasi berasal dari klas Actinobacteria dan 34,4\% merupakan anggota klas Bacillus. Sistem penyaringan bertingkat yang digunakan pada hatchery dapat mengurangi jumlah bakteri yang masuk ke medium pemeliharaan hewan budidaya, namun keberadaan bakteri dalam tubuh hewan budidaya turut dipengaruhi oleh proses fisiologi hewan tersebut.

\section{Kesimpulan dan Saran}

\section{Kesimpulan}

Isolat bakteri yang teridentifikasi
memiliki kesamaan karakteristik dengan
Bacillus, Micrococcus, Streptomyces,
Enterobacter dan Escherichia. Nilai SPC lola
dan kima masih berada dalam kisaran normal,
namun MPN-nya berada di atas normal untuk
standar budidaya hatchery untuk tujuan
konsumsi.

\section{Saran}

Disarankan untuk uji lanjut tingkat molekular untuk mengetahui jenis bakteri yang teridentifikasi.

\section{Ucapan Terima Kasih}

Penelitian ini terlaksana atas dukungan sebagian dana program Riset Unggulan Terpadu XII tahun 2006, terima kasih juga kepada Pengelola Hatchery Universitas Hasanuddin P. Barrang Lompo atas kerjasama yang baik selama pengambilan sampel.

\section{Daftar Pustaka}

Anonim. 2005. Iklim usaha yang kondusif bagi pengembangan akuakultur di Indonesia. Makalah Akuakultur Indonesia. Ditjen Budidaya DKP.

Armand. 1999. Pengaruh Penggunaan Antibiotik Streptomycin Sulfat dengan Dosis yang Berbeda terhadap Sintasan Kima Air (Tridacna derasa). Skripsi Fakultas Ilmu Kelautan dan Perikanan Universitas Hasanuddin.

Austin, B. 1988. Marine Microbiology. Cambridge University Press, New York.

Bergey, Kreig, N.R., Holt, J.G. and Sneath, P.H.A. 1994. Bergey's Manual of Determinative Bacteriology. Ninth Edition, William \& Wilkuns, Baltimore.

Cappucino, J.G. and Sherman, N. 1992. Mikrobiology A Laboratory Manual $3^{\text {rd }}$ Edition, The Benjamin Cummings Publishing Company Inc. Redwood City, California.

Ekawati, P. and Mursyanti, E. 2006. Mutu Bakteriologis Pindang Tongkol (Euthynnus affinis) yang Berasal dari Beberapa Pasar di Yogyakarta. Biota XI (1): 40-46.

Gontang, E.A., Fenical, W. and Jensen, P.R. 2007. Phylogenetic diversity of gram-positive bacteria culture from marine sediments. Appl. \& Env. Micro. 173 (10): 3272.

Hadioetomo, R.S. 1990. Mikrobiologi Dasar dalam Praktek Teknik dan Prosedur Laboratorium. Gramedia, Jakarta.

Lay, B.W. 1994. Analisis Mikroba di Laboratorium. Raja Grafindo Persada. Jakarta

Lejab, S. 2006. Kualitas Sistem Penyaringan Air Laut di Tinjau dari Segi Bakteriologi pada Hatchery Lola (Trochus niloticus L.) dan Kima sisik (Tridacna squamosa Linn). Skripsi Fakultas Matematika dan Ilmu Pengetahuan Alam Universitas Hasanuddin, Makassar.

Litaay, M., Niartiningsih, A., Suryati, E., Yusuf, S. dan Sopamena, A. 2006a. Tingkat keberhasilan rekrutmen larva lola (Trochus niloticus L.) pada substrat yang berbeda. Pros. Konferensi Akuakultur Indonesia.

Litaay, M., Apriadi, Yusuf, S. dan Arifin. 2006b. Pertumbuhan dan sintasan juwana lola (Trochus niloticus Linn) dan kima sisik (Tridacna squamosa) pada ocean nursery P. Barrang Lompo. Bull. Penelitian Seri Hayati 9 (2): 161-171.

Mac Faden, J.F. 1991. Biochemical Test for Identification of Medical Bacteria. Baltimore. 
Marwan, 1996. Pengaruh Pemberian Berbagai Jenis Makanan Alami terhadap Pertumbuhan dan Tingkat Kelangsungan Hidup Larva Lola (Trochus niloticus) di Hatchery P.Barrang Lompo, Ujung Pandang. Skripsi. Fakultas Ilmu Kelautan dan Perikanan. Universitas Hasanuddin. Ujung Pandang.

Marwoto, S. 2001. Jenis-jenis Hayati yang dilindungi Perundang-Undangan Indonesia. In: Noerdjito, M. \& Maryanto, I. (Eds.). Moluska, pp. 135-136. Cetakan Kedua. Puslit Biologi LIPI. Cibinong.

Niartiningsih, A. 2000. Pengaruh pemberian Zooxanthella dari Sumber yang Berbeda terhadap Pertumbuhan Larva Kima Sisik (Tridacna squamosa). Bull. Ilmu Peternakan dan Perikanan.VI: 233-239.

Niartiningsih, A. 2001. Analisis Mutu Zooxanthella dari Berbagai Inang dan Pertumbuhannya terhadap Sintasan dan Pertumbuhan Juvenil Kima Sisik. Disertasi. Program Studi Ilmu Pertanian Universitas Hasanuddin.

Niartiningsih, A., Latama, G., Nessa, M.N. dan Ishak, Q. 2001. Pengaruh Pemberian Obat Cacing Mebendazole dengan Dosis yang Berbeda terhadap Pertumbuhan dan Sintasan Juvenil Kima Sisik (Tridacna squamosa) yang Terinfeksi Cacing. J. Ilmiah Sains dan Teknologi 2 (2): 23-34.

Niartiningsih, A., Indrawati, E., Hadijah, M. dan Syahruni. 2004a. Pengaruh Waktu Pemberian Zooxanthella terhadap Sintasan dan Pertumbuhan Larva Kima Sisik Tridacna squamosa. Torani J. Ilmu Kelautan dan Perikanan 3 (14): 121-126.
Niartiningsih, A., Tantu, A.G., Hadijah, M. dan Salam, A. 2004b. Pengaruh Kepadatan Zooxanthella terhadap Sintasan dan Pertumbuhan Larva Kima Sisik Tridacna squamosa. Torani J. Ilmu Kelautan dan Perikanan 4 (14): 181186.

Nontji, A. 2002. Laut Nusantara. Penerbit Djambatan, Jakarta.

Pelczar, M.J. dan Chan, E.C.S. 1986. Dasar-Dasar Mikrobiologi cetakan I, UI Press, Jakarata.

Rheinheimer, G. 1992. Aquatic Microbiology. 4th ed. John Wiley, New York..

Suaib, M. 1995. Pengaruh Pemberian Pupuk Zuewerzur Amoniak (ZA) dengan Dosis yang Berbeda terhadap Pertumbuhan Juvenil Kima Air (Tridacna derasa) di Hatchery P. Barrang Lompo. Skripsi Program Studi Ilmu Kelautan Universitas Hasanuddin.

Schulze, A.D., Alabi, A.O., Tattersall-Sheldrake, A.R. and Miller, K.M. 2006. Bacterial diversity in marine hatchery: balance between pathogenic and potentially probiotic bacterial strain. Aquaculture 256 (50): 1-4.

Volk, A.M. and Wheeler, M.F. 1993. Mikrobiologi Dasar. Terjemahan Sri Lestari. Edisi V. Jilid II. Penerbit Erlangga. Jakarta.

Yusuf, S., Litaay, M., Niartiningsih, A., Budimawan and Fatmawati. 2006. Spawning of the topshell (Trochus niloticus L.) using different induce methods. Torani Special edition. 16 (5): 403408. 